DOI 10.38129/Ann.Yur.Ist.2020.4.1.23

УДК 614.461(614.455:614.441:614.442:614:446)

\title{
ОТРАЖЕНИЕ ПРОКАЗЫ В СРЕДНЕВЕКОВЫХ ЕВРОПЕЙСКИХ ИСТОЧНИКАХ ЦЕРКОВНОГО (КАНОНИЧЕСКОГО) И СВЕТСКОГО ПРАВА
}

\author{
ОЛЬГА КЕЛЛЕР (Тюбинген, Федеративная Республика Германия)*
}

\section{ВВЕДЕНИЕ}

Лепра (или проказа), вне всякого сомнения, особая болезнь 1 .

К сожалению, невозможно сегодня с точностью определить, как часто была выявлена эта болезнь в средневековой Европе, а также установить региональные отличия появления лепры и то, как видоизменялось количество больных на протяжении столетий. Однако, одно можно сказать вполне достоверно: максимальное распространение проказы приходится на XIII век. Как раз на это время приходится расивет средневековых городов, а именно, увеличение числа городского населения. Перед городскими стенами строились специальные заведения для размещения прокажённых, или так называемые лепрозории. На протяжении же Раннего Нового времени можно констатировать определённый спад болезни по абсолютно неизвестным и неясным нам причинам ${ }^{2}$. Эта болезнь нашла отражение в средневековых источниках исторического, религиозного и правового характера. Лепра периода Раннего Средневековья вполне характерна для Западной Европы, а посему, безусловно, существовала острая необходимость урегулировать там обращение с больными проказой.

\section{ЕВРОПЕЙСКИЕ ИСТОЧНИКИ КАНОНИЧЕСКОГО ПРАВА О БОЛЬНЫХ ЛЕПРОЙ И ИХ ПРАВАХ}

Итак, первые раннесредневековые свидетельства, упоминающие лепру, восходят к 549 году, а именно: к «Постановлениям» Орлеанского церковного

\footnotetext{
${ }^{1}$ Toellner, Richard. Zur Einführung: Lepra ist anders / Richard Toellner // Lepra - Gestern und Heute. 15 wissenschaftliche Essays zur Geschichte und Gegenwart einer Menschheitsseuche. Gedenkschrift zum 650-jährigen Bestehen des Rektorats MünsterKinderhaus. Hrsg. von R. Toellner. - Münster, 1992. - S. 1-6.

2 Jankrift, Kay Peter. Mit Gott und schwarzer Magie. Medizin im Mittelalter / Kay Peter Jankrift. - Darmstadt: Wissenschaftliche Buchgesellschaft, 2005. - 173 S. - S. 121.
} 
Coбора ${ }^{3}$.

«Постановления» Орлеанского церковного Собора обязывали епископов, игравших во Франции важную политическую роль, снабжать больных проказой в их епископских владениях одеждой и пищей.

На третьем Лионском церковном Соборе 583 года это решение было повторено ещё раз и дополнено поправкой, согласно которой епископам не позволялось разрешать больным проказой перемещаться в другие епископства 4 .

Следующим документом, отмечающим, что больных проказой следует изолировать от здоровых членов общества, является каролингский Капитулярий 789 года5 ${ }^{5}$. В нём указывалось, что больным проказой нельзя «смешиваться» с населением Пфальца6.

Лищь Третий Латеранский (а в традииии римско-католической изеркви 11-й Вселенский) собор 1179 года собрал воедино все правовые положения относительно заболевших проказой 7 . Там было сформулировано следующее: больные, проказой, которые не могут жить со здоровыми, не должны разделять с ними ни божьих домов, ни кладбищ. В противоположность этому, им предписывалось возводить церкви и места погребения именно в том месте, где они «объединялись для совместного проживания». Больные лепрой осъобождались от уплаты обязательной церковной десятины. Наряду с этим, Третий Латеранский собор 1179 года предусматривал создание с целью проживания в них больных так называемых специальных учреждений лепрозориев для прокажённых, которые до этого существовали лишь спорадически, то есть рассеянно.

Лондонский церковный Собор повторяет в 1200 году «Положения» Третьего Латеранского собора 1179 года. При великом понтифике Папе

${ }^{3}$ De Clercq, Charles. Conscilia Galliae A. 511 - A. 695 (= Corpus Christianorum. Series Latina CXLVIII A) / Charles de Clercq. - Tournhout, 1973. - S. 156.

${ }^{4}$ Merzbacher, Friedrich. Die Leprosen im alten kanonischen Recht / Friedrich Merzbacher // Zeitschrift der Savigny-Stiftung für Rechtsgeschichte. - Kanonistische Abteilung 84 (1967). - S. 27-45.

${ }_{5}^{5}$ Boretius, Alfred; Krause, Victor (Hrsg.). Capitularia Regnum Francorum (MGH legum sectio II) / Alfred, Boretius; Victor, Krause. - Hannover 1897. - Capit II Nr. 298, I: Nr. 64.

${ }^{6}$ Keil, Gundolf. Der Aussatz im Mittelalter / Gundolf, Keil // Aussatz - Lepra - HansenKrankheit. Ein Menschheitsproblem im Wandel. Hrsg. von Jörn Henning Wolf. - Teil II. Aufsätze (= Kataloge des Dt. Medizinhist. Museums, Beihefte 1). - Würzburg 1986. - S. 88. ${ }^{7}$ Alberigo, Josef; Leonardi, Claudio u.a. (Hrsg.). Consilium Oecumenicorum Decreta / Josef, Alberigo; Claudio, Leonardi. - Bologna, 1973. - S. 222. 
Римском Григории IX (1227-1241) они наконец-то нашли своё выражение в общеправовых нормах ${ }^{8}$.

\section{ЕВРОПЕЙСКИЕ СРЕДНЕВЕКОВЫЕ ИСТЧОНИКИ СВЕТСКОГО ПРАВА О БОЛЬНЫХ ЛЕПРОЙ И ИХ ПРАВАХ}

Намного реже, чем источники религиозного характера (вернее, источники канонического права), лепру отражали и светские правовые источники Западной и Центральной Европы периода Средневековья.

В Лангобардском королевстве судьбу больных проказой регулировал появившийся в 643 году «Свод законов» обычного права лангобардов, кодифицированный при короле Ротари («Edictus Rothari») ${ }^{9}$. Этот «Свод законов» короля Ротари, или так называемая «Лангобардская Правда», первое в мировой истории свидетельство письменной фиксации прав больных лепрой! В нём указано, что больной проказой представляет собой своего рода «мертвого» человека («tamquam mortuus»), то есть такой человек терял любые права и всевозможные претензии на наследование. Он больше не имел никакого отношения к наследственному праву, не мог обращаться в суд, не имел права распоряжаться своим имуществом и не мог совершать никаких покупок ${ }^{10}$. Помимо этого, «Свод законов» короля Ротари сообщает, что после того, как устанавливался точный диагноз, больной проказой должен в тот же день, когда это установлено, обязательно покинуть свой дом. Несмотря на то, что заболевшему надлежало покинуть дом, по всей видимости, члены его семьи всё-таки продолжали снабжать его продовольствием и одеждой.

Каким образом определялся диагноз? Для этого созывалась специальная Комиссия, состоящая из судьи («iudex») и представителей из народа. Конечно, упоминая данный факт, можно провести определённые параллели с библейскими предписаниями касательно поведения с больными, подозреваемыми в наличии данного заболевания, однако, есть и отличия,

${ }^{8}$ Jankrift, Kay Peter. Leprose als Streiter Gottes. Institutionalisierung und Organisation des Ordens vom Heiligen Lazarus zu Jerusalem von seinen Anfängen bis zum Jahre 1350 (= Vita Regularis. Ordnungen und Deutungen religiösen Lebens im Mittelalter 4) / Kay Peter, Jankrift. - Münster, 1996. - S. 10.

${ }^{9}$ Die Gesetze der Langobarden. Übersetzt von Franz Beyerle. - Bd. 1: Edictus Rothari (=Germanenrechte 3). - Witzenhausen, 1962. - S. 35.

${ }_{10}$ Reicke, Siegfried. Das deutsche Spital und sein Recht im Mittelalter / Siegfried Reicke. Zweiter Teil: Das deutsche Spitalrecht (= Kirchenrechtliche Abhandlungen 113/114). Stuttgart, 1932. - S. 261. 
ведь получается, что в раннесредневековый период создавалась специальная инстанция, занимающаяся решением подобного вопроса ${ }^{11}$.

Лишь почти шесть столетий спустя, первый правовой сборник Германии под названием «Саксонское Зерцало» Эйке фон Репкова, созданный примерно около 1225 года, снова обратил своё внимание и посвятил отдельные положения своего правового текста больным этим страшным заболеванием ${ }^{12}$. Некоторые строки памятника правовой мысли XIII в., также как и шесть веков назад, посвящались праву наследования больных проказой 13 . Однако, тут же следует отметить те изменения, которые упоминались в «Саксонском Зерцале» и затрагивали право владения и наследственное право больных. Согласно данным «Зерцала саксов», заболевшим лепрой дозволялось и далее распоряжаться своей собственностью, которую они получили до выявления у них данной смертоносной болезни. Но это, в принципе, не меняло то, что по «Саксонскому Зерцалу» больные лепрой в целом считались «мёртвыми» в правовом смысле. Это значит, что они не могли представать перед судом. Наряду с этим, они не могли совершать никаких правовых действий. Конечно, на практике всё могло выглядеть, да и выглядело несколько иначе. В XIII и XIV вв. налицо своего рода ограничения на право владения собственностью больными проказой, ибо огромное количество существовавших в эти два века заведений по уходу за больными под названием «лепрозории» появилось именно за счёт собственности таких больных. Лишь в период Позднего Средневековья больным лепрой частично возвращают их права обратно ${ }^{14}$.

Кроме того, хотелось бы подчеркнуть, что правовые сборники Средневековья затрагивали в своих текстах не только правовой статус обычных больных проказой. Так, в появившемся на 50 лет позднее «Саксонского Зерцала» в 1275 году на юге Германии сборнике «Швабское Зерцало» речь идёт о короле. Причём король, который заболел подобной болезнью после выборов, - сообщает «Швабское Зерцало», - не мог быть

11 Jankrift, Kay Peter. Mit Gott und schwarzer Magie. Medizin im Mittelalter / Kay Peter Jankrift. - Darmstadt: Wissenschaftliche Buchgesellschaft, 2005. - 173 S. - S. 122.

12 Eike von Repgow. Der Sachsenspiegel. Hrsg. von Claudia Schott (= Manesse-Bibliothek der Weltliteratur). - Zürich, 1984. - S. 39.

13 Uhrmacher, Martin. Leprosorien im Mittelalter und früher Neuzeit (= Geschichtlicher Atlas der Rheinlande. Beiheft VIII, 5) / Martin, Uhrmacher. - Köln, 2000. - S. 6.

14 Jankrift, Kay Peter. Mit Gott und schwarzer Magie. Medizin im Mittelalter / Kay Peter Jankrift. - Darmstadt: Wissenschaftliche Buchgesellschaft, 2005. - 173 S. - S. 123. 
переизбран. Специально для него должен был быть найден здоровый «помощник» 15 .

\section{Dr. habil. Olga Keller (Tubingen, Germany)}

Reflection of lepra in the medieval sources of the church (canonical) and public law

The maximum spread of leprosy occurs in the XIII century AD. It was at this time that the heyday of medieval cities fell, namely, an increase in the number of urban population. In front of the city walls, special institutions were built to accommodate lepers, or the socalled leper colony. During the Early Modern Age, we can state a certain decline in the disease for reasons completely unknown and unclear to us. This disease is reflected in medieval legal sources. The following legal monuments govern the social situation of leprosy patients: Decrees of the Orleans Church Cathedral, Decisions of the Lyons Church Cathedral, Decisions of the Lateran Ecumenical Council, Lombard Truth, Saxon Mirror, Swabian Mirror.

Key words: Leprosy, Leper Colony, Canon Law, Legal Status of Patients.

доктор исторических наук Ольга Келлер (Тюбинген, Германия)

Отражение проказы в средневековых европейских источниках церковного (канонического) и светского права

Максимальное распространение проказы приходится на XIII век. Как раз на это время приходится расцвет средневековых городов, а именно, увеличение числа городского населения. Перед городскими стенами строились специальные заведения для размещения прокажённых, или так называемые лепрозории. На протяжении же Раннего Нового времени можно констатировать определённый спад болезни по абсолютно неизвестным и неясным нам причинам. Эта болезнь нашла отражение в средневековых источниках правового характера. Регулируют общественное положение больных проказой следующие юридические памятники: Постановления Орлеанского церковного собора, Постановления Лионского церковного собора, Постановления Латеранского Вселенского собора, Лангобардская правда, Саксонское Зерцало, Швабское Зерцало.

Ключевые слова: лепра, лепрозории, каноническое право, юридический статус пациентов.

доктор історичних наук Ольга Келлер (Тюбінген, Німеччина)

Відображення прокази у середньовічних європейських джерелах церковного (канонічного) та світського права

Максимальне поширення прокази припадає на XIII століття - період Високого Середньовіччя. Якраз у цей час відбувається стрімкий культурний та політико-

${ }^{15}$ Ibidem. 
правовий розквіт середньовічних міст, збільшення числа міського населення. Перед міськими стінами будувалися спеціальні заклади для розміщення прокажених, або так звані лепрозорії. Протягом же Раннього Нового часу можна констатувати певний спад хвороби по абсолютно невідомим і незрозумілим нам причин. Ця хвороба знайшла відображення в середньовічних джерелах правового характеру. Регулюють суспільне становище хворих на проказу наступні юридичні пам'ятники: Постанови Орлеанського церковного собору, Постанови Ліонського церковного собору, Постанови Латеранського Вселенського собору, Лангобардська варварська правда, Саксонське Зерцало, Швабське Зерцало.

Ключові слова: лепра, лепрозорії, канонічне право, юридичний статус пацієнтів.

* Келлер Ольга Борисовна - доктор исторических наук, доцент, доцент кафедры истории Древнего Мира и Средних веков философского факультета Тюбингенского университета Эберхарда и Карла, доцент кафедры истории Нового и Новейшего времени исторического факультета Белорусского государственного университета в Минске.

E-mail: olga.keller@mail.ru. 